\title{
PENINGKATAN PRESTASI BELAJAR MELAPORKAN ISI BACAAN MELALUI METODE DISKUSI
}

\author{
Karyadi \\ SDN 3 Depok Kec. Bendungan Kab. Trenggalek \\ Email: karyadi574@gmail.com
}

\begin{tabular}{l}
\hline Tersedia Online di \\
\hline http://www.jurnal.unublitar.ac.id/ \\
index.php/briliant \\
\hline \\
\hline Sejarah Artikel \\
\hline Diterima pada 16 Januari 2017 \\
Disetuji pada 22 Januari 2017 \\
Dipublikasikan pada 1 Februari \\
2017 Hal. 80 - 91 \\
\hline Kata Kunci: \\
prestasi belajar, melaporkan isi \\
bacaan, diskusi
\end{tabular}

\begin{abstract}
Abstrak: Penelitian ini menggunakan penelitian tindakan (action research) sebanyak tiga putaran. Setiap putaran terdiri dari empat tahap yaitu: rancangan, kegiatan dan pengamatan, refleksi, dan refisi. Sasaran penelitian ini adalah siswa Kelas II SD Negeri 3 Depok Kecamatan Bendungan Kabupaten Trenggalek semester I Tahun pelajaran 2012/2013. Dari hasil analis didapatkan bahwa metode diskusi memiliki dampak positif dalam meningkatkan prestasi belajar siswa.hal ini dapat dilihat dari semakin mantapnya pemahaman siswa terhadap materi yang disampaikan guru (ketuntasan belajar meningkat dari sklus I, II, dan III) yaitu masing-masing $64,00 \%, 80,00 \%$, dan $88,00 \%$. Kesimpulan dari penelitian ini adalah metode Diskusi mempunyai pengaruh positif, yaitu dapat meningkatkan motivasi belajar siswa.
\end{abstract}

Belajar bahasa tak lepas dari pengembangan wacana akan keberadaan bahasa tersebut, sedangkan wacana yang tersedia baik lisan maupun tulisan dipenuhi dengan muatan budaya. Oleh karenanya ketika kita mempelajari bahasa tanpa mempelajarai budayannya maka jelas yang akan terjadi adalah kesalah pahaman dan salah interpretasi dalam penggunaan bahasa. Apabila hal ini terus berlanjut dipastikan konflik budaya dalam diri seorang pembelajar bahasa akan menumbuhkan sikap negatif terhadap bahasa yang dipelajarinya. Sikap negatif ini akan bisa menghambat kelancaran proses belajar bahasa.

Mengingat pentingnya kegiatan berbahasa, seyogyanya guru dapat memupuk kegiatan berbahasa tersebut, dengan cara atau teknik yang mudah untuk dipahami oleh anak. Dalam hal ini khususnya untuk mengenalkan kosakata bahasa Indonesia, kapada siswa. Cara pengenalannya dapat diajarkan dengan menggunakan beberapa teknik atau cara.

Dalam pembelajaran bahasa Indonesia, proses penalaran deduktif untuk menguatkan pemahan yang sudah dimiliki oleh siswa perlu dikembangkan lebih lanjut. Hal ini sesuai dengan Tujuan pembelajaran bahasa Indonesia yaitu untuk melatih cara berfikir secara sistematis, logis, kritis, kreatif dan konsisten.

Pembelajaran bahasa Indonesia tidak lagi mengutamakan pada penyerapan melalui pencapaian informasi, tetapi lebih mengutamakan pada pengembangan kemampuan dan pemrosesan informasi. Untuk itu aktiIItas peserta didik perlu ditingkatkan melalui latihan-latihan atau tugas bahasa Indonesia dengan bekerja kelompok kecil dan menjelaskan ide-ide kepada orang lain. 
Langkah-langkah tersebut memerlukan partisipasi aktif dari siswa. Untuk itu perlu ada metode pembelajaran yang melibatkan siswa secara langsung dalam pembelajaran. Adapun metode yang dimaksud adalah metode pembelajaan Diskusi.

Penguasaan teknik tulis menulis dalam bahasa Indonesia memiliki aspek beragam. Diantaranya dapat digunakan sebagai sarana untuk mengembangkan pengetahuan, menyampaikan pesan, bentuk kata.

Prestasi Belajar adalah suatu hasil yang dicapai setelah ia melalui suatu proses belajar yang berwujud angka simbol-simbol yang menyatakan kemampuan siswa dalam suatu materi pelajaran tertentu. a) Faktor yang mempengaruhi prestasi. Menurut Ahmadi (1990:130), Prestasi belajar dipengaruhi oleh banyak faktor antara lain faktor internal dan faktor eksternal. Dan untuk lebih jelasnya akan diuraikan sebagai berikut: 1) Yang tergolong faktor internal adalah faktor yang berasal dari dalam diri indiIIdu yang terdiri dari: a) Faktor jasmaniah yang sifatnya bawaan atau yang diperoleh, misalnya penglihatan, pendengaran struktur tubuh. b) Faktor Psikologis terdiri atas: -) Faktor intelektif yang meliputi kecerdasan, kecapakan yang dimiliki, -) Faktor non-intelektif yang meliputi unsur kepribadian, kebiasaan, emosi minat, motivasi. 2) Yang tergolong faktor eksternal adalah, a) Faktor sosial yang terdiri atas: -) Lingkungan keluarga, -) Lingkungan sekolah, -) Lingkungan masyarakat, -) Lingkungan kelompok, b) Faktor budaya seperti adat istiadat, dan kesenian, Faktor-faktor tersebut saling berinteraksi secara langsung ataupun tidak langsung dalam mencapai prestasi belajar. Dan sebagaimana dijelaskan dimuka bahwa prestasi belajar adalah suatu hasil yang dicapai siswa melalui proses belajar yang berwujud angka atau simbol yang menyatakan kemampuan siswa dalam suatu materi pelajaran tertentu.

Sebelum penulis mengartikan apa yang dimaksud metode diskusi terlebih dahulu akan mengartikan mengenai metode itu sendiri. Menurut Sorachmad mengungkapkan, metode adalah cara yang fungsinya merupakan alat untuk mencapai tujuan.

Setelah kita artikan apa yang dimaksud metode, tinggal kita artikan mengenai diskusi dimana pengertian diskusi menurut Soemirat adalah "Diskusi adalah penglibatan dua atau lebih indiIIdu yang berinteraksi secara verbal dan saling berhadapan muka, mengenai tujuan atau sarana yang sudah tertentu melalui cara tukar menukar informasi (information sharing), pengalaman sendiri (self maintenance) atau pemecahan masalah (problem solIIng).

Metode diskusi adalah suatu cara penyampian suatu bahan pelajaran dimana guru menugaskan kelompok pelajaru melaksanakan percakapan ilmiah, hingga diperoleh suatu keputusan yang benar yang disepakati bersama yang tertuang dalam kurikulum berbasis kompetensi.

\section{METODE}

Design penelitian dalam penelitian ini adalah Penelitian tindakan kelas (PTK). PTK adalah penelitian tindakan yang dilaksanakan oleh guru di dalam kelas. PTK pada hakikatnya merupakan rangkaian "riset-tindakan", yang dilakukan secara siklik, dalam rangka memecahkan masalah, sampai masalah itu terpecahkan. Sependapat dengan uraian tersebut, Karwono (1988:42) 
mendefinisikan PTK sebagai suatu bentuk kajian yang bersifat reflektif oleh pelaku tindakan, untuk meningkatkan kemantapan rasional dari tindakan-tinakan mereka dalam melaksanakan tugas. Menurut Kurt Lewin (1991:70), PTK terdiri dari empat komponen, yaitu: (1) perencanaan (planning), (2) tindakan (acting), (3) pengamatan (observasi), dan (4) refleksi (reflecting).

\section{Tempat Penelitian}

Berdasarkan pertimbangan bahwa peneliti sebagai pengajar telah menemukan permasalahan yang signifikan dalam Kelas II SD Negeri 3 Depok Kecamatan Bendungan Kabupaten Trenggalek. Oleh karenanya, peneliti mimilih kelas tersebut sebagai tempat penelitian. Penentuan tempat tersebut didasarkan pada metode purposive atau purposive sampling area. yaitu suatu metode penelitian yang didasarkan pada pertimbangan dari peneliti itu sendiri guna memperoleh data yang diperlukan.

\section{Subjek Penelitian}

Subjek penelitian ini adalah siswa Kelas II SD Negeri 3 Depok Kecamatan Bendungan Kabupaten Trenggalek. Subyek ini ditentukan menggunakan metode purposive dengan pertimbangan bahwa siswa tersebut masih mengalami kesulitan di kelas. Subjek penelitian adalah obyek yang diteliti, baik berupa manusia, benda, peristiwa maupun gejala yang terjadi (Ali, 1985:54).

\section{Teknik Pengumpulan Data}

Data dalam Penelitian Tindakan Kelas ini akan diambil dari test dan hasil observasi pelaksanaan tiap siklus. Methode pengumpulan data akan dijabarkan sebagai berikut: 1) Test, Dalam penelitian ini, tes digunakan untuk memperoleh data primer berkaitan dengan kemampuan siswa. Arikunto (1998:139) mendefinisikan Test sebagai seperangkat pertanyaan, latihan, atau alat pengukur, yang digunakan untuk mengukur suatu kemampuan, pengetahu-an, dari seorang individu atau kelompok.

Lebih lanjut, dalam penelitian ini menggunakan achievement test sebagai instrument untuk memperoleh data primer. Achievement test digunakan untuk mengukur kemampuan siswa setelah mendapat proses pengajaran di kelas. berkaitan dengan penelitian ini, test yang diberikan harus valid dan reliable. Test yang dibeikan valid apabila mewakili sample kemampuan siswa atau komponen yang telah diajarkan dikelas berdasarkan kurikulum yang ada dan indikator yang digunakan sebagai acuan.

Test yang valid harus reliable karena secara konsisten dapat digunakan sebagai acuan atau ukuran. Berdasarkan pendapat Weir (1990:3) "jika sebuah test valid, maka test itu juga reliable". maka apabila test tersebut disusun berdasarkan kurikulum yang ada dan indikator yang digunakan sebagai acuan, maka test tersebut juga dianggap reliable. Oleh karenanya, test yang digunakan dalam penelitian ini telah dianggap valid dan reliable karena telah memenuhi acuan seperti tersebut diatas. Dan peneliti tidak perlu melaksanakan test untuk mengetahui kevalidan dan kereliabelan dari test yang digunakan. 2) Observation, Observasi atau pengamatan dilaksanakan pada setiap siklus. Observasi ini 
digunakan untuk mendapatkan data proses pelaksanaan tindakan dalam kelas. Hasil observasi yang dilakukan akan dijadikan sebagai bahan refleksi di akhir pelaksanaan tiap siklus. Peneliti menggunakan observsi participatif dimana peneliti ikut serta dalam melak-sanakan tindakan sambil mengadakan pengamatan dikelas.

\section{Prosedur Penelitian}

Deskripsi umum penelitan yang dilaksanakan, Penelitian Tindakan Kelas dilaksanakan berdasarkan urutan yang pasti. Urutan ini mengikuti model siklus yang terdiri dari empat aktiIItas, yaitu: a) Planning/perencanaan, b) Action/Implementation/pelaksanaan, c) Observation and evaluation/ pengamatan dan evaluasi, d). Reflection/refleksi.

Deskripsi penelitian secara detail, a). Planning/perencanaan tindakan Dalam perencanaan tindakan disiapkan beberapa hal sebagai berikut: 1) memilih materi yang diajarkan sesuai kurikulum. 2) menyusun RPP siklus pertama, 3) menyiapkan instrumen (test). b) Implementation pelaksanaa tindakan, pelaksanan siklus pertama dilaksanakan selama jam pelajaran aktif disekolah sesuai dengan jadwal yang ada. Pelaksanaan siklus pertama dilaksanakan sesuai dengan RPP yang telah dibuat dan pada akhir tindakan siswa diberi test guna mengetahui peningkatan /ketuntasan belajar siswa setelah mendapatkan perlakuan tindakan. c) Observation and Evaluation /pengamatan dan evaluasi, Observasi adalah hal yang penting guna mengetahui tindakan yang dilakukan di kelas. Observasi akan dilaksanakan untuk mengetahui apakan guru telah melaksanakn RPP dengan baik atau tidak. Selaen itu, observasi juga digunakan untuk mengetahui kegiatan siswa selama proses belajar mengajar. Dalam observasi ini guru menggunakan catatan lapangan atau field note sebagai bahan evaluasi. Data peningkatan kemampuan siswa atau ketuntasan belajar siswa diketahui melalui hasil test yang diberikan setiap akhir pelaksanaan siklus. Berdasarkan petunjuk pelaksanaan belajar mengajar kurikulum 1994 (Depdikbud, 1994), yaitu seorang siswa telah tuntas belajar bila telah mencapai skor $65 \%$ atau nilai 65 , dan kelas disebut tuntas belajar bila di kelas tersebut terdapat $85 \%$ yang telah mencapai daya serap lebih dari atau sama dengan 65\%.d). Reflection / refleksi, Refleksi digunakan untuk mengetahui gambaran umum tingkat ketuntasan belajar siswa dan pelaksanan siklus yang dilakukan. Apakah siklus yang dilakukan telah mencapai target atau belum. Data yang diambil akan dianalisa secara kuantitatif dan dideskripsikan untuk menjawab permasalahan yang ada.

\section{HASIL}

Data yang diperoleh dalam penelitian ini berupa observasi berupa pengamatan pengelolaan metode pembela-jaran diskusi dalam kelompok dan penga-matan aktiIItas siswa dan guru pada akhir pengajaran, dan data tes formatif siswa pada setiap siklus. Data tes formatif untuk menge-tahui peningkatan prestasi belajar siswa setelah diterapkan metode pembelajaran diskusi. 


\section{Siklus I}

Tahap Perencanaan, Pada tahap ini peneliti mempersiapkan perangkat pengajaran yang terdiri dari rencana pelajaran 1 , LKS 1 , soal tes formatif 1 dan alat-alat pengajaran yang mendukung. Selain itu juga dipersiapkan lembar observasi pengolahan metode pengajaran Diskusi, dan lembar observasi aktiIItas guru dan siswa, b) Tahap Kegiatan dan Pelaksanaan, Pelaksanaan kegiatan belajar mengajar untuk siklus I bersama dengan pelaksaaan belajar mengajar. Sebagai pengamat adalah guru Kelas IV SD Negeri 3 Depok Kecamatan Bendungan kabupten Trenggalek.

Pada akhir proses belajar mengajar siswa diberi tes formatif I dengan tujuan untuk mengetahui tingkat keberhasilan siswa dalam proses belajar mengajar yang telah dilakukan. Adapun data hasil penelitian pada siklus I adalah sebagai berikut:

Tabel 1. Nilai Tes I

\begin{tabular}{|c|c|c|c|c|}
\hline \multirow{2}{*}{$\begin{array}{l}\text { No. } \\
\text { Urut }\end{array}$} & \multirow{2}{*}{$\begin{array}{l}\text { Nama } \\
\text { Siswa }\end{array}$} & \multirow{2}{*}{ Nilai } & \multicolumn{2}{|c|}{ Keterangan } \\
\hline & & & $\mathrm{T}$ & TT \\
\hline 1 & A 1 & 60 & & $\sqrt{ }$ \\
\hline 2 & A 2 & 65 & & $\sqrt{ }$ \\
\hline 3 & A 3 & 75 & $\sqrt{ }$ & \\
\hline 4 & A 4 & 70 & $\sqrt{ }$ & \\
\hline 5 & A 5 & 70 & $\sqrt{ }$ & \\
\hline 6 & A 6 & 70 & $\sqrt{ }$ & \\
\hline 7 & A 7 & 70 & $\sqrt{ }$ & \\
\hline 8 & A 8 & 60 & & $\sqrt{ }$ \\
\hline 19 & A 9 & 70 & $\sqrt{ }$ & \\
\hline 10 & A 10 & 70 & $\sqrt{ }$ & \\
\hline 11 & A 11 & 70 & $\sqrt{ }$ & \\
\hline 12 & A 12 & 60 & & $\sqrt{ }$ \\
\hline 13 & A 13 & 70 & $\sqrt{ }$ & \\
\hline 14 & A 14 & 65 & & $\sqrt{ }$ \\
\hline 15 & A 15 & 70 & $\sqrt{ }$ & \\
\hline 16 & A 16 & 60 & & $\sqrt{ }$ \\
\hline 17 & A 17 & 60 & & $\sqrt{ }$ \\
\hline 18 & A18 & 65 & & $\sqrt{ }$ \\
\hline 19 & A 19 & 75 & $\sqrt{ }$ & \\
\hline 20 & A 20 & 75 & $\sqrt{ }$ & \\
\hline 21 & A 21 & 75 & $\sqrt{ }$ & \\
\hline 22 & A 22 & 75 & $\sqrt{ }$ & \\
\hline 23 & A 23 & 75 & $\sqrt{ }$ & \\
\hline 24 & A 24 & 75 & $\sqrt{ }$ & \\
\hline 25 & A 25 & 65 & & $\sqrt{ }$ \\
\hline \multicolumn{2}{|c|}{ Jumlah } & 1715 & 16 & 9 \\
\hline
\end{tabular}


\% Skor Tercapai 68,60

$\begin{array}{llll}\text { Keterangan: } & \mathrm{T} & & : \text { Tuntas } \\ & \mathrm{TT} & : 16 & : \text { Tidak Tuntas } \\ & \text { Jumlah siswa yang tuntas } & : 9 \\ & \text { Jumlah siswa yang belum tuntas } & : 9 \\ \text { Klasikal } & : \text { Belum tuntas }\end{array}$

Tabel 2. Rekapitulasi Hasil Tes Formatif Siswa pada Siklus I

\begin{tabular}{|c|l|c|}
\hline No & \multicolumn{1}{|c|}{ Uraian } & Hasil Siklus I \\
\hline 1 & Nilai rata-rata tes formatif & 68,60 \\
2 & Jumlah siswa yang tuntas belajar & 16 \\
3 & Persentase ketuntasan belajar & 64,00 \\
\hline
\end{tabular}

Dari tabel di atas dapat dijelaskan bahwa dengan menerapkan metode Diskusi diperoleh nilai rata-rata Pemahaman belajar siswa adalah $68.60 \%$ dan ketuntasan belajar mencapai 64,00\% atau ada 16 siswa dari 25 siswa sudah tuntas belajar. Hasil tersebut menunjukkan bahwa pada siklus pertama secara klasikal siswa belum tuntas belajar, karena siswa yang memperoleh nilai $\geq 65$ hanya sebesar 64,00\% lebih kecil dari persentase ketuntasan yang dikehendaki yaitu sebesar $85 \%$. Hal ini disebabkan karena siswa masih merasa baru dan belum mengerti apa yang dimaksudkan dan digunakan guru dengan menerapkan metode Diskusi. c) Refleksi, Dalam pelaksanaan kegiatan belajar mengajar diperoleh informasi dari hasil pengamatan sebagai berikut: 1) guru kurang baik dalam pengelolaan waktu. 2) Guru kurang baik dalam memotivasi siswa dan dalam menyampaikan tujuan pengajaran. 3) Siswa kurang bitu antusias selama pengajaran berlangsung. d) Refisi, Pelaksanaan kegiatan belajar mengajar pada siklus I ini masih terdapat kekurangan, sehingga perlu adanya reIIsi untuk dilakukan pada siklus berikutnya. 1) Guru perlu mendistribusikan waktu secasra baik dengna menambahkan informasi-informasi yang dirasa perlu dan memberi catatan, 2) Guru perlu lebih terampil dalam memotivasi siswa dan lebih jelas dalam menyampaikan tujuan pengajaran. Dimana siswa diajak untuk terlibat langsung dalam setiap kegiatan yang akan dilakukan. 3) Guru harus lebih terampil dan bersemangat dalam memotivasi siswa sehingga siswa bisa lebih antusias.

\section{Siklus II}

Tahap perencanaan, Pada tahap ini peneliti mempersiapkan perangkat pengajaran yang terdiri dari rencana pelajaran 2, LKS, 2, soal tes formatif II dan alat-alat pengajaran yang mendukung. Selain itu juga dipersiapkan lembar observasi pengelolaan metode pengajaran Diskusi dan lembar observasi guru dan siswa. b) Tahap kegiatan dan pelaksanaan, Pelaksanaan penelitian siklus II peneliti bertindak sebagai guru. Adapun proses belajar mengajar mengacu pada rencana pelajaran dengan memperhatikan revisi pada siklus I, sehingga kesalahan atau kekurangan pada siklus I tidak terulanga lagi pada siklus II.

Pengamatan (observasi) dilaksa-nakan bersamaan dengan pelak-sanaan belajar mengajar. Sebagai pengamat adalah guru Kelas IV SD Negeri 3 Depok Kecamatan Bendungan Kabupaten Trenggalek. 
Pada akhir proses belajar mengajar siswa diberi tes formatif II dengan tujuan untuk mengetahui tingkat keberhasilan siswa dalam proses belajar mengajar yang telah dilakukan. Instrument yang digunakan adalah tes formatif II. Adapun data hasil penelitian pada siklus II adalah sebagai berikut.

Tabel 3. Nilai Tes II

\begin{tabular}{|c|c|c|c|c|}
\hline \multirow{2}{*}{$\begin{array}{l}\text { No. } \\
\text { Urut }\end{array}$} & \multirow{2}{*}{$\begin{array}{l}\text { Nama } \\
\text { Siswa }\end{array}$} & \multirow{2}{*}{ Nilai } & \multicolumn{2}{|c|}{ Keterangan } \\
\hline & & & $\mathrm{T}$ & TT \\
\hline 1 & A 1 & 65 & & $\sqrt{ }$ \\
\hline 2 & A 2 & 70 & $\sqrt{ }$ & \\
\hline 3 & A 3 & 80 & $\sqrt{ }$ & \\
\hline 4 & A 4 & 80 & $\sqrt{ }$ & \\
\hline 5 & A 5 & 75 & $\sqrt{ }$ & \\
\hline 6 & A 6 & 75 & $\sqrt{ }$ & \\
\hline 7 & A 7 & 75 & $\sqrt{ }$ & \\
\hline 8 & A 8 & 75 & $\sqrt{ }$ & \\
\hline 19 & A 9 & 80 & $\sqrt{ }$ & \\
\hline 10 & A 10 & 75 & $\sqrt{ }$ & \\
\hline 11 & A 11 & 75 & $\sqrt{ }$ & \\
\hline 12 & A 12 & 65 & & $\sqrt{ }$ \\
\hline 13 & A 13 & 80 & $\sqrt{ }$ & \\
\hline 14 & A 14 & 65 & & $\sqrt{ }$ \\
\hline 15 & A 15 & 70 & $\sqrt{ }$ & \\
\hline 16 & A 16 & 70 & $\sqrt{ }$ & \\
\hline 17 & A 17 & 70 & $\sqrt{ }$ & \\
\hline 18 & A18 & 80 & $\sqrt{ }$ & \\
\hline 19 & A 19 & 65 & & $\sqrt{ }$ \\
\hline 20 & A 20 & 80 & $\sqrt{ }$ & \\
\hline 21 & A 21 & 80 & $\sqrt{ }$ & \\
\hline 22 & A 22 & 80 & $\sqrt{ }$ & \\
\hline 23 & A 23 & 80 & $\sqrt{ }$ & \\
\hline 24 & A 24 & 80 & $\sqrt{ }$ & \\
\hline 25 & A 25 & 65 & & $\sqrt{ }$ \\
\hline \multicolumn{2}{|c|}{ Jumlah } & 1855 & 20 & 5 \\
\hline \multicolumn{5}{|c|}{$\begin{array}{l}\text { Jumlah Skor } 1855 \\
\text { Jumlah Skor Maksimal Ideal } 2500 \\
\% \text { Skor Tercapai } 74,20\end{array}$} \\
\hline
\end{tabular}

$\begin{array}{lll}\text { Keterangan: } & \text { T } & \\ & \text { TT } & \text { : Tuntas } \\ \text { Jumlah siswa yang tuntas } & : 20 \\ \text { Jumlah siswa yang belum tuntas } & : 5 \\ \text { Klasikal } & : \text { Belum tuntas }\end{array}$


Tabel 4. Rekapitulasi Hasil Tes Formatif Siswa pada Siklus II

\begin{tabular}{|c|l|c|}
\hline No & \multicolumn{1}{|c|}{ Uraian } & Hasil Siklus II \\
\hline 1 & Nilai rata-rata tes formatif & 74,20 \\
2 & Jumlah siswa yang tuntas belajar & 20 \\
3 & Persentase ketuntasan belajar & 80,00 \\
\hline
\end{tabular}

Dari tabel di atas diperoleh nilai rata-rata Pemahaman belajar siswa adalah $74,20 \%$ dan ketuntasan belajar mencapai $80,00 \%$ atau ada 20 siswa dari 25 Siswa sudah tuntas belajar. Hasil ini menunjukkan bahwa pada siklus I ini ketuntasan belajar secara klasikal telah mengalami peningkatan sedikit lebih baik dari siklus I. Adanya peningkatan hasil belajar siswa ini karena setelah guru menginformasikan bahwa setiap akhir pelajaran akan selalu diadakan tes sehingga pada pertemuan berikutnya siswa lebih termotivasi untuk belajar. Selain itu siswa juga sudah mulai mengerti apa yang dimaksudkan dan dinginkan guru dengan menerapkan metode Diskusi, c) Refleksi, Dalam pelaksanaan kegiatan belajar diperoleh informasi dari hasil pengamatan sebagai berikut: 1) Memotivasi siswa, 2) Membimbing siswa merumuskan kesimpulan/menemukan konsep, 3) Pengelolaan waktu. d) Revisi Rancangan, Pelaksanaan kegiatan belajar pada siklus II ini masih terdapat kekurangan-kekurangan. Maka perlu adanya revisi untuk dilaksanakan pada siklus III antara lain: 1) Guru dalam memotivasi siswa hendaknya dapat membuat siswa lebih termotivasi selama proses belajar mengajar berlangsung. 2) Guru harus lebih dekat dengan siswa sehingga tidak ada perasaan takut dalam diri siswa baik untuk mengemukakan pendapat atau bertanya. 3) Guru harus lebih sabar dalam membimbing siswa merumuskan kesimpulan/menemukan konsep. 4) Guru harus mendistribusikan waktu secara baik sehingga kegiatan pengajaran dapat berjalan sesuai dengan yang diharapkan. 5) Guru sebaiknya menambah lebih banyak contoh soal dan memberi soal-soal latihan pada siswa untuk dikerjakan pada setiap kegiatan belajar mengajar.

\section{Siklus III}

Tahap Perencanaan, Pada tahap ini peneliti mempersiapkan perangkat pengajaran yang terdiri dari rencana pelajaran 3, LKS 3, soal tes formatif 3 dan alat-alat pengajaran yang mendukung. Selain itu juga dipersiapkan lembar observasi pengelolaan pengajaran penemuan terbimbing dan lembar observasi aktilltas guru dan siswa, b) Tahap kegiatan dan pengamatan, Pelaksanaan kegiatan belajar mengajar untuk siklus I dilaksanakan mengacu pada rencana pelajaran dengan memperhatikan revisi pada siklus II, sehingga kesalahan atau kekurangan pada siklus III tidak terulang lagi pada siklus III.

Pengamatan (observasi) dilaksanakan bersamaan dengan pelaksanaan belajar mengajar. Sebagai pengamat adalah guru Kelas IV SD Negeri 3 Depok Kecamatan Bendungan Kabupaten Trenggalek.

Pada akhir proses belajar mengajar siswa diberi tes formatif III dengan tujuan untuk mengetahui tingkat keberhasilan siswa dalam proses belajar mengajar yang telah dilakukan. Instrumen yang digunakan adalah tes formatif III. Adapun data hasil penelitian pada siklus III adalah sebagai berikut: 
Tabel 5. Nilai Tes III

\begin{tabular}{|c|c|c|c|c|}
\hline \multirow{2}{*}{$\begin{array}{l}\text { No. } \\
\text { Urut }\end{array}$} & \multirow{2}{*}{$\begin{array}{l}\text { Nama } \\
\text { Siswa }\end{array}$} & \multirow{2}{*}{ Nilai } & \multicolumn{2}{|c|}{ Keterangan } \\
\hline & & & $\mathrm{T}$ & $\mathrm{TT}$ \\
\hline 1 & A 1 & 65 & & $\sqrt{ }$ \\
\hline 2 & A 2 & 70 & $\sqrt{ }$ & \\
\hline 3 & A 3 & 80 & $\sqrt{ }$ & \\
\hline 4 & A 4 & 80 & $\sqrt{ }$ & \\
\hline 5 & A 5 & 75 & $\sqrt{ }$ & \\
\hline 6 & A 6 & 75 & $\sqrt{ }$ & \\
\hline 7 & A 7 & 75 & $\sqrt{ }$ & \\
\hline 8 & A 8 & 75 & $\sqrt{ }$ & \\
\hline 19 & A 9 & 80 & $\sqrt{ }$ & \\
\hline 10 & A 10 & 75 & $\sqrt{ }$ & \\
\hline 11 & A 11 & 80 & $\sqrt{ }$ & \\
\hline 12 & A 12 & 65 & & $\sqrt{ }$ \\
\hline 13 & A 13 & 80 & $\sqrt{ }$ & \\
\hline 14 & A 14 & 65 & & $\sqrt{ }$ \\
\hline 15 & A 15 & 75 & $\sqrt{ }$ & \\
\hline 16 & A 16 & 80 & $\sqrt{ }$ & \\
\hline 17 & A 17 & 80 & $\sqrt{ }$ & \\
\hline 18 & A18 & 80 & $\sqrt{ }$ & \\
\hline 19 & A 19 & 80 & $\sqrt{ }$ & \\
\hline 20 & A 20 & 80 & $\sqrt{ }$ & \\
\hline 21 & A 21 & 80 & $\sqrt{ }$ & \\
\hline 22 & A 22 & 80 & $\sqrt{ }$ & \\
\hline 23 & A 23 & 80 & $\sqrt{ }$ & \\
\hline 24 & A 24 & 80 & $\sqrt{ }$ & \\
\hline 25 & A 25 & 70 & $\sqrt{ }$ & \\
\hline \multicolumn{2}{|c|}{ Jumlah } & 1885 & 22 & 3 \\
\hline \multicolumn{5}{|c|}{$\begin{array}{l}\text { Jumlah Skor } 1885 \\
\text { Jumlah Skor Maksimal Ideal } 2500 \\
\% \text { Skor Tercapai } 75,40\end{array}$} \\
\hline
\end{tabular}

$\begin{array}{llll}\text { Keterangan: } & \mathrm{T} & & : \text { Tuntas } \\ & \mathrm{TT} & & : \text { Tidak Tuntas } \\ & \text { Jumlah siswa yang tuntas } & : 22 & \\ \text { Jumlah siswa yang belum tuntas } & : 3 & \\ \text { Klasikal } & : \text { Belum tuntas }\end{array}$

Tabel 6. Rekapitulasi Hasil Tes Formatif Siswa pada Siklus III

\begin{tabular}{|c|l|c|}
\hline No & \multicolumn{1}{|c|}{ Uraian } & Hasil Siklus \\
& & III \\
\hline 1 & Nilai rata-rata tes formatif & 75,40 \\
2 & Jumlah siswa yang tuntas belajar & 22 \\
3 & Persentase ketuntasan belajar & 88,00 \\
\hline
\end{tabular}


Berdasarkan tabel diatas diperoleh nilai rata-rata tes formatif sebesar $75,40 \%$ dan dari 25 siswa yang telah tuntas sebanyak 22 siswa dan 3 siswa belum mencapai ketuntasan belajar. Maka secara klasikal ketuntasan belajar yang telah tercapai sebesar $88,00 \%$ (termasuk kategori tuntas). Hasil pada siklus I ini mengalami peningkatan lebih baik dari siklus I. Adanya peningkatan hasil belajara pada siklus I ini dipengaeruhi oleh adanya peningkatan kemampuan guru dalam menerapkan metode Diskusi sehingga siswa menjadi lebih terbiasa dengan pengajaran seperti ini sehingga siswa lebih mudah dalam memahami materi yang telah diberikan. c) Refleksi, Pada tahap ini akan dikaji apa yang telah terlaksana dengan baik maupun yang masih kurang baik dalam proses belajar mengajar dengan penerapan metode pengajaran Diskusi. Dari data-data yang telah diperoleh dapat duraikan sebagai berikut: 1) Selama proses belajar mengajar guru telah melaksanakan semua pengajaran dengan baik. Meskipun ada beberapa aspek yang belum sempurna, tetapi persentase pelaksanaannya untuk masing-masing aspek cukup besar. 2) Berdasarkan data hasil pengamatan diketahui bahwa siswa aktif selama proses belajar berlangsung. 3) Kekurangan pada siklus-siklus sebelumnya sudah mengalami perbaikan dan peningkatan sehingga menjadi lebih baik. 4) Hasil belajar siswa pada siklus I mencapai ketuntasan, d) ReIIsi Pelaksanaan, Pada siklus I guru telah menerapkan metode pengajaran Diskusi dengan baik dan dilihat dari aktiIItas siswa serta hasil belajar siswa pelaksanaan proses belajar mengajar sudah berjalan dengan baik. Maka tidak diperlukan reIIsi terlalu banyak, tetapi yang perlu diperhatikan untuk tindakah selanjutnya adalah memaksimalkan dan mepertahankan apa yang telah ada dengan tujuan agar pada pelaksanaan proses belajar mengajar selanjutnya penerapan metode pengajaran Diskusi dapat meningkatkan proses belajar mengajar sehingga tujuan pengajaran dapat tercapai.

\section{PEMBAHASAN}

\section{Ketuntasan Hasil belajar Siswa}

Melalui hasil penelitian ini menunjukkan bahwa pengajaran Diskusi memiliki dampak positif dalam meningkatkan prestasi belajar siswa.hal ini dapat dilihat dari semakin mantapnya pemahaman siswa terhadap materi yang disampaikan guru (ketuntasan belajar meningkat dari sklus I, II dan III) yaitu masing-masing 64,00\%, 80,00\%, dan 88,00\%. Pada siklus III ketuntasan belajar siswa secara klasikal telah tercapai.

\section{Kemampuan Guru dalam Mengelola Pengajaran}

Berdasarkan analisis data, diperoleh aktiIItas siswa dalam proses metode pengajaran Diskusi dalam kelompok di setiap siklus mengalami peningkatan. Hal ini berdampak positif terhadap prestasi belajar siswa yaitu dapat ditunjukkan dengan meningkatnya nilai rata-rata siswa pada setiap siklus yang terus mengalami peningkatan.

\section{Aktivitas Guru dan Siswa Dalam Pengajaran}

Berdasarkan analisis data, diperoleh aktiIItas siswa dalam proses pengajaran Bahasa dengan metode pengajaran Diskusi dalam kelompok yang paling dominan adalah bekerja dengan menggunakan alat/media, mendengarkan 
/memperhatikan penjelasan guru, dan Diskusi antar siswa/antara siswa dengan guru. Jadi dapat dikatakan bahwa aktivitas siwa dapat dikategorikan aktif. Sedangkan untuk aktiIItas guru selama pengajaran telah melaksanakan langkahlangkah metode pengajaran Diskusi dalam kelompok dengan baik. Hal ini terlihat dari aktiIItas guru yang muncul di antaranya aktiIItas membimbing dan mengamati siswa dalam mengerjakan kegiatan LKS/menemukan konsep, menjelaskan /melatih menggunakan alat, memberi umpan balik/evaluasi/Tanya jawab dimana prosentase untuk aktiIItas di atas cukup besar.

\section{KESIMPULAN}

Berdasarkan pembahasan dan analisis yang telah dilakukan serta dari hasil kegiatan pengajaran yang dilakukan selama tiga siklus dapat disimpulkan sebagai berikut: 1) Metode Pengajaran Diskusi memiliki dampak positif. Hal ini dapat di identifikasi dari kenaikan Persentase prestasi ketuntasan belajar siswa secara signifikan setelah mendapatkan perlakuan dari tiap siklus yaitu siklus II 64,00\%, Siklus II 80,00\%, dan Siklus III 88,00\%. 2) Salah satu Pengaruh dari Penerapan metode pengajaran Diskusi adalah Meningkatnya motivasi belajar siswa pada mata pelajaran Bahasa Indonesia .

\section{SARAN}

Setelah melakukan penelitian selama tiga siklus, maka saran yang dapat di berikan adalah sebagai berikut ; 1) metode pembelajaran diskusi hendaknya selalu dikembangkan sebagai upaya untuk mencari konsep ideal dalam sebuah proses belajar mengajar. 2) Perlunya alat peraga atau media yang benar-benar efektif dalam pengajaran Bahasa Indonesia .

\section{DAFTAR RUJUKAN}

Arikunto, Suharsimi. 2002. Prosedur Penelitian Suatu Pendekatan Praktek. Jakarta: Rineksa Cipta

Ali, Muhammad. 1996. Guru Dalam Proses Belajar Mengajar. Bandung: Sinar Baru Algesindon.

Dayan, Anto. 1972. Pengantar Metode Statistik Deskriptif, tt. Lembaga Penelitian Pendidian dan Penerangan Ekonomi.

Hadi, Sutrisno. 1983. Metodologi Research, Jilid 1. Yogyakarta: YP. Fak. Psikologi UGM.

Lee, W.R. 1985. Language Teaching Games and Contests. London: Oxfortd University Press.

MelIIn, L. Siberman. 2004. Aktif Learning, 101 Cara Belajar Siswa Aktif. Bandung: Nusamedia dan Nuansa.

Riduawan. 2005. Belajar Mudah Penelitian untuk Guru-Karyawan dan Peneliti Pemula. Bandung: Alfabeta.

Sudjana, Nana. 1989. Dasar-dasar Proses Belajar Mengajar. Bandung: Sinar Baru.

Sukmadinata, Nana Syaodih. 2005. Metode Penelitian Pendidikan. Bandung: PT. Remaja Rosdakarya.

Surakhmad, Winarno. 1990. Metode Pengajaran Nasional. Bandung: Jemmars.

90 BRILLIANT: Jurnal Riset dan Konseptual

Volume 2 Nomor 1, Februari 2017 
Weed, Gretchen, E. 1971. Using Games in Teaching Children. ELEC Bulletin No. 32. Winter. Tokyo. 